\title{
APPELLATE REVIEW OF SENTENCES AND THE NEED FOR A REVIEWABLE RECORD
}

If there is one rule in the federal criminal practice which is firmly established, it is that the appellate court has no control over a sentence which is within the limits allowed by statute. ${ }^{1}$

Adherence to the rule against sentence review has occasionally resulted in clearly excessive but unchallengeable sentences ${ }^{2}$ and in unjustified disparity in punishment for similar crimes. ${ }^{3}$ Not surprisingly, though the rule is still widely followed, ${ }^{4}$ it has been subjected to relentless criticism. ${ }^{5}$ In response to such criticism and to frequent in-

1. Gurera v. United States, 40 F.2d 338, 340-41 (8th Cir. 1930). There is statutory authority for sentence review of various kinds in fifteen states. See ALAs. Stat. ANN. § 12.55.120 (1973); MONT. Rev. CODE ANN. § 95-2501 et seq. (1969); and statutes reviewed in ABA Project on STandards for Criminal Justice, STANDARdS Relating to Appellate Review of Sentence App. A (Approved Draft, 1968). The courts of at least six other states have interpreted their general appellate mandates to include such authority. See id. at 14-15.

2. One of many examples is the case of a fifty-one-year-old first offender who was given a fifty-two year sentence for one narcotics sale, despite the lack of any aggravating circumstances. Although the appeals court felt that the sentence was "greater than should have been imposed," it pronounced itself powerless to review the sentence. Smith v. United States, 273 F.2d 462, 467 (10th Cir. 1959). For other examples of excessive sentences, sce ABA ProJECT, supra note 1, at 22; Kennedy, Justice Is Found in the Hearts and Minds of Free Men, 30 F.R.D. 401, 424-25 (1961).

3. For example, two similar cases of check forgery were punished, respectively, by a thirty-day and a fifteen-year sentence. "Our examination of these two cases indicated no significant differences for sentencing purposes." M. Frankel, Criminal Sentences 21-22 (1973), quoting James V. Bennett, former Director of the Federal Bureau of Prisons.

In 1958, the Senate Judiciary Committee reported: "During 1957 average sentences to imprisonment for all types of crimes varied from 8.9 months in New Hampshire to 54.6 months in western Oklahoma. . . . Even the proportion of convicted offenders placed on probation for all types of crimes varies widely, ranging from 15.3 percent in western Texas to 68.8 percent in Vermont." S. REP. No. 2013, 85th Cong., 2d Sess. 4 (1958). For a general survey of sentence disparity, see Zumwalt, The Anarchy of Sentencing in the Federal Courts, 57 Judicature 96 (1973) (compiled from U.S. Bureau of Prisons, Statistical Table Number 7 (1968) ).

4. See, e.g., Moore v. United States, 454 F.2d 286 (6th Cir. 1972); United States v. Dzialak, 441 F.2d 212 (2d Cir. 1971); United States v. Lloyd, 431 F.2d 160 (9th Cir. 1970), cert. denied, 403 U.S. 911 (1971). See cases cited note 19 infra.

5. See, e.g., Burr, Appellate Review as a Means of Controlling Criminal Sentencing Discretion-A Workable Alternative, 33 U. PITr. L. Rev. 1 (1971); Cobwi, Disparity in Sentences and Appellate Review of Sentencing, 25 RUTGERS L. REv. 207 (1971); Hall, Reduction of Criminal Sentences on Appeal, 37 Colum. L. REv. 521 (1937); Sobeloff, The Sentence of the Court: Should There Be Appellate Review? 41 A.B.A.J. 13 (1955). 
stances of unfairness, federal appeals courts have increasingly avoided the rule against sentence review. Given the apparent breadth of these judicially developed avoidance techniques, it can probably be said that an appeals court now has ample precedent for the review of any sentence it considers outrageous.

Despite the initial encouragement that these developments might afford him, a convicted defendant seeking sentence review still faces two major problems. First, the defendant's access to review is a function of the extent to which the circuit in which he was tried has adopted one or more of these techniques for avoiding the rule of nonreview, and there is great variation in this respect among circuits. Second, access to serious review is dependent upon the existence of a reviewable record. At present, a sentencing judge is usually not required to disclose to the defendant or to an appeals court either the presentence report or the judge's grounds for a particular sentence. ${ }^{0}$ This freedom to operate in secret, - if at all justifiable, accords only with a system where sentencing deeisions are not reviewable. If sentences may be subjected to appellate scrutiny, the compilation of a reviewable record of the sentencing decision would appear to be mandated. This Note will trace the origin and the history of the judge-made rule against sentence review. The various means of avoiding the rule will then be discussed, leading to the conclusion that in some jurisdictions the rule has been completely undermined. Fmally, it will be argued that the increasing availability of review necessitates a change from secrecy to openness in the sentencing process.

\section{History of the RULE AgAINST REVIEW OF SENTENCES}

\section{Origin of the Rule}

The federal rule agaimst appellate review of sentences was first propounded in 1917 in the landinark case of Freeman v. United States. ${ }^{7}$ The Ninth Circuit initially decided that there had been no error in the trial court's conviction and sentencing of Freeman. In dictum, the court then announced that even if a sentencing error were found, the appeals court would have no power to review it. That conclusion rested upon the fact that although the old circuit courts had been given a statutory power "to pronounce final sentence" 8 and had

6. See notes 94-99, 115-25 infra and accompanying text.

7. 243 F. 353 (9th Cir. 1917), cert. denied, 249 U.S. 600 (1919). Freeman, who had used the mails to inform persons that he could cure all ailments if paid certain sums, was convicted of mail fraud and sentenced to one year's imprisonment.

8. Act of Mar. 3, 1879, ch. 176, § 3, 20. Stat. 354. 
exercised it, ${ }^{9}$ such an express grant of power was omitted from the 1891 statute creating the modern courts of appeals. ${ }^{10}$ In Freeman, the Ninth Circuit focused on this omission and accordingly held itself powerless to review a legal sentence imposed by the district court. ${ }^{11}$

The court need not have attributed significance to the omission, for another section of the 1891 Act adopted for the new courts of appeals the same "methods and system of review"12 under which the old circuit courts had operated. Since that system of review included review of sentences by the old circuit courts, ${ }^{13}$ this language in the 1891 Act could have been construed to provide a basis for sentence review by the new courts of appeals. Moreover, the Freeman court did not necessarily have to conclude that the appellate power to review sentences had been omitted from the 1891 statute, under which

[t] he appellate court [could] affirm, modify, or reverse the judgment, decree, or order brought before it for review, or [could] direct such judgment, decree, or order to be rendered, or such further proceedings to be had by the inferior court as the justice of the case [might] require. ${ }^{14}$

Under the 1891 statute, sentence revision clearly could have been considered a legitimate exercise of the power to "modify" a judgment order. ${ }^{15}$

Nevertheless, the dubious statutory construction in Freeman has survived; since Freeman, no federal appeals court has expressly reviewed the severity of a sentence as a normal incident of appellate

9. See United States v. Wynn, 11 F. 57 (1882); Bates v. United States, 10 F. 92 (1881).

10. See Act of Mar. 3, 1891, ch. 517, 26 Stat. 826.

11. $243 \mathrm{~F}$. at 357.

12. Act of Mar. 3, 1891 , ch. $517, \S 11,26$ Stat. 829 , provided:

All provisions of law now in force regulating the methods and system of review .... shall regulate the methods and system of appeals ... . provided for in this act in respect of the circuit courts of appeals.

"Methods and systems" was later interpreted by the Supreme Court to comprehend the power of the federal courts of appeals. See Ballew v. United States, 160 U.S. 187, 201-02 (1895).

13. See note 8 supra and accompanying text.

14. Act of June $1,1872, \mathrm{ch} .255, \S 2,17$ Stat. 197 (made effective with respect to courts of appeals by Act of Mar. 3, 1891, ch. 517, $\$ 11,26$ Stat. 829). As to the effect of the 1891 Act, the House Judiciary Committee reported: "It destroys the "judicial despotism' of the present system by creating an intermediate appellate court, with power to revise the final judgments of the district courts in all cases, civil and criminal, except ... where the fine is not over $\$ 300$ and does not involve imprisonment." H.R. REP. No. 1295, 51st Cong., 1st Sess. 3 (1890).

15. Several state courts have made such an interpretation. See, e.g., State v. Ledbetter, 83 Idaho 451, 364 P.2d 171 (1961); Blake v. State, 186 Ark. 77, 52 S.W.2d 644 (1932). 
power. ${ }^{18}$ Though judges have occasionally questioned the Freeman interpretation, ${ }^{17}$ the general judicial attitude was best expressed by Judge Frank in his review of the sentences imposed on Julius and Ethel Rosenberg, who were later executed for leaking atomic secrets to the Russians. "[Because of] undeviating federal precedents," the judge wrote, "it is clear that the Supreme Court alone is in a position to hold that [the relevant federal statute] confers authority to reduce a sentence which is not outside the bounds set by a valid statute."18

The Supreme Court, however, has never explicitly ruled on the existence of an inherent appellate power to review sentences directly, except to hold that the district judge's discretion is very broad:

[I]t is true that the imposition of the . . . penalty ... seems unduly severe; but there may have been other facts and circumstances before the trial court properly influencing the extent of the punishment. In any event, the matter was one for that court . . . . ${ }^{19}$

Given the lack of a statutory or Supreme Court mandate to support the rule against sentence review and given the increasing criticism of the rule, ${ }^{20}$ it is not surprising that appellate judges have often strained to formulate means of avoiding the rule in order to review excessive sentences.

\section{Avoidance of the Rule by the Courts of Appeals}

An appeals court could ask two questions about a sentence: one is whether the sentencing procedure was fair; the other is whether the judge's discretionary decision to impose a particular sentence was substantially appropriate. Since the landmark 1948 Supreme Court case of Townsend $v$. Burke, ${ }^{21}$ it has been commonly said that an appeals court can ask the first question regarding sentencing procedure but not

16. For the modern grant of federal appellate power, substantially unchanged from the 1891 version, see 28 U.S.C. $\$ 2106$ (1970).

17. See, e.g., Smith v. United States; 273 F.2d 462, 468 (10th Cir. 1959) (Murrah, C.J., dissenting); United States v. Rosenberg, 195 F.2d 583, 604-07 (2d Cir. 1952).

18. United States v. Rosenberg, 195 F.2d 583, 604, 606-07 (2d Cir. 1952).

19. Blockburger v. United States, 284 U.S. 299, 305 (1932); cf. United States v. Tucker, 404 U.S. 443, 447 (1972) ("a sentence imposed by a federal district judge, if within statutory limits, is generally not subject to review"). See also Gore v. United States, 357 U.S. 386 (1958).

It is important to note, however, that the quotation from the Supreme Court's opmion in Blockburger would, by its own terms, seem not to pertain to a case in which the reviewing court is fully informed as to the "facts and circumstances" which influenced the severity of the sentence.

20. See authorities cited note 5 supra. In 1968 the American Bar Association approved a report favoring sentence review. See ABA PRoJECT, supra note 1 , at 7.

21. 334 U.S. 736 (1948). 
the second regarding substance. Ostensibly to justify the more limited procedural review, the federal appellate courts have on a number of occasions advanced three rationales: the obligation to ensure due process in sentencing, the need to protect a defendant's right to refrain from selfincrimination, and the desire to enforce correct interpretation of sentencing statutes. ${ }^{22}$ But even though these rationales appear to concern procedure, it is a principal thesis of this Note that these notions have in effect disguised review of the severity or substance of sentences as well. In addition to this de facto substantive review, some appellate courts have engaged in direct substantive review of sentence severity by exercising their supervisory control over the lower federal courts and, on occasion, even by engaging in explicit review of a trial court's discretion.

Ensuring due process. The Townsend Court establislied the principle that, while the severity of a sentence is generally not subject to appellate review, the process of sentencing is reviewable. In Townsend the defendant was not represented by counsel at sentencing, and the sentencing judge was misinformed as to the defendant's prior criminal record. Holding that this combination of circumstances deprived the defendant of due process, ${ }^{23}$ the Supreme Court vacated the sentence.

Several recent decisions, which lave emphasized defects in the sentencing process, have used the due process rationale to greatly extend Townsend's inroad into the area of the sentencing judge's discretion. Whereas Townsend's sentence was based on false infor-

22. The procedural rationales discussed here are those which appear to have been stretched to justify substantive review. Often due process and other rationales have actually been used purely to guarantee procedural review. See note 23 infra.

23. 334 U.S. at 740-41. Flowing readily from Townsend have been numerous sentences disapproved because the sentencing judge considered "improper factors." Unlike United States v. Weston, 448 F.2d 626 (9th Cir. 1971), cert. denied, 404 U.S. 1061 (1972), where a discretionary decisiou of the sentencing judge was considered improper (see text accompanying notes 25-29 infra), these other cases have found sentencing procedures defective on due process grounds. See, e.g., United States v. Tucker, 404 U.S. 443 (1972) (sentencing judge's reliance on prior convictions, for which defendant had not been represented by counsel, violated defendant's right to counsel); Kelly v. United States, No. 73-1240 (6th Cir. Nov. 29, 1973) (reversed and remanded because sentencing judge did not await confirmation of the challenged validity of prior convictions of the defendant); United States v. Powell, No. 73-1210 (4th Cir. Nov. 19,1973 ) (review of sentence uplield, since the record below, as distinguislied from information surfacing in related hitigation, failed to support the judge's material behef that the defendant had operated as a "ringleader" in the crime for which he liad been couvicted); United States v. Stockwell, 472 F.2d 1186 (9th Cir.), cert. denied, 411 U.S. 984 (1973) (where the sentencing judge apparently penalized the defendant for liaving stood trial, the defendant's right to trial was violated); Haller v. Robbins, 409 F.2d 857 (1st Cir. 1969) (seutencing judge improperly considered prejudicial information conveyed ex parte by the prosecutor). 
mation, ${ }^{24}$. in United States $v$. Weston ${ }^{25}$ the sentencing judge was persuaded by unsubstantiated hearsay as to the great extent of the defendant's unproven criminality. $^{28}$ Notwithstanding the appeals court's recognition of strong authority that a sentencing judge is not bound by the evidentiary rules which govern a trial, ${ }^{27}$ the Ninth Circuit reinanded the case for resentencing, holding broadly that "the 'no review of sentence' rule does not preclude reviewing the propriety of the reasons for imposing a particular sentence."28 Although the Ninth . Circuit carefully distinguished "reviewing a sentence" from reviewing the procedure or the "propriety of the reasons,"29 it significantly chose to examine the sentencing procedure in a case where a first narcotics offender had been given an exceptionally harsh maximum sentence of twenty years' imprisonment.

In Townsend and Weston, the sentencing judges had expressly placed an improper emphasis on false or doubtful inforination. ${ }^{30}$. However, in Virgin Islands v. Turner, ${ }^{31}$ nothing in the record proinpted "procedural" review; the only evidence before the Third Circuit which indicated that the sentencing judge had considered such improper factors was the severity of the sentence:

A ten-year sentence for larceny of merchandise worth under $\$ 1000$ ... seems to us high. . . . [W] e are led to wonder whether the evidence the government was unable to develop at the trial found itself in the sentencing proceedings or the judge's mind. ${ }^{32}$

Despite its nominal deference to the rule that the severity of a sentence is not reviewable, the Third Circuit delicately suggested that the defendant "move for a reduction of sentence so that the district court may have an opportunity to reconsider this matter."33 Thus, it ap-

24. 334 U.S. at 740 .

25. 448 F.2d 626 (9th Cir. 1971), cert. denied, 404 U.S. 1061 (1972).

26. The presentence report unreliably indicated that Weston, who had been convicted of possession of heroin, was a major narcotics dealer. Id. at 630 .

27. E.g., Gregg v. United States, 394 U.S. 489 (1969); Williams v. New York, 337 U.S. $241,246-47$ (1949).

28. 448 F.2d at 632. But see United States v. Sacher, 182 F.2d 416, 421 (2d Cir. 1950), where the court held that the sentencing judge's "reason for the length of the sentence would not affect its validity and should be ignored on appeal."

29. 448 F.2d at 631-32.

30. See Townsend v. Burke, 334 U.S. 736, 739-40 (1948); United States v. Weston, 448 F.2d 626, 630 (9th Cir. 1971).

31. 409 F.2d 102 (3d Cir. 1968).

32. Id. at 104. The Third Circuit stated that, having charged Turner with making unauthorized credit card purchases totaling $\$ 800$, the Government in opening its caso irresponsibly referred to "niore than $\$ 4000$ in fraudulent charges." Id. at 103.

33. Id. at 104. 
pears that the Townsend rule, if inanipulated by a well-intentioned and moderately artful court of appeals, is no bar to effective review of the severity of a sentence.

Protecting the defendant's privilege against self-incrimination. A review of sentencing "procedure" inay also be deemed necessary to preserve a defendant's right to refrain froin self-incrimination, though the circuits have varied in the degree to which they have protected a defendant's fifth amendinent rights at sentencing. The typical situation involves a defendant who has pleaded not guilty but who has nevertheless been convicted. The trial judge, at a sentencing hearing, asks the defendant whether he would like to admit his guilt. Even though the context makes it clear that the defendant would receive a lighter sentence for "coming clean," the defendant persists in denying guilt.

When confronted by these facts in Thomas $v$. United States, ${ }^{34}$ the Fifth Circuit found that procedural error, inter alia, justified a remand for resentencing. ${ }^{35}$ Although Thomas' refusal to confess guilt technically preserved his fifth amendment rights, the harsh sentence was held to be an improper "judicially imposed penalty for exercising constitutionally guaranteed rights."36

Reviewing similar facts, the Ninth Circuit in Gollaher $v$. United States $^{37}$ found no procedural error. Upon conviction, "the judge must proceed upon the basis that the defendant is guilty." The defendant's prospect for rehabilitation, as arguably indicated by his willingness to admit fault, was therefore held to be a valid consideration at sentencing. ${ }^{39}$

The defendant Gollaher faced a maximum sentence of twentyseven years of imprisonment; he was sentenced to two. The defendant

34. 368 F.2d 941 (5th Cir. 1966).

35. In remanding for resentencing, the court of appeals also relied upon its supervisory power over the district courts. See notes 57-67 infra and accompanying text.

36. 368 F.2d at 946. "Still open to [Thomas] were the processes of motion for new trial (mcluding the opportunity to discover new evidence), appeal, petition for certiorari, and collateral attack." Id. at 945 . All these remedies would have been jeopardized if Thomas had confessed; there also would have been the possibility of prosecution for perjury had he done so. See generally Note, The Influence of the Defendant's Plea on Judicial Determination of Sentence, 66 YALE L.J. 204, 220 (1956).

37. 419 F.2d 520 (9th Cir.), cert. denied, 396 U.S. 960 (1969).

38. Id. at 530-31.

39. Cf. Armpriester v. United States, 256 F.2d 294 (4th Cir. 1958) (after a plea of guilty, the sentencing judge properly considered a confession which had been illegally obtained from the defendant); Hanneman v. State, 50 Wis. $2 \mathrm{~d} 689,184$ N.W.2d 896 (1971) (since a guilty plea is a waiver of the privilege against-self-incrimination, the sentencing judge properly considered defendant's refusal to testify at a sentencing hearing). 
Thomas faced a maximum of twenty-five years and was sentenced to twenty-five. The Gollaher court, finding no procedural error, was careful to note the length of the sentences imposed in both cases. ${ }^{40}$ Whether the Ninth Circuit will decide to protect a defendant's fifth amendinent rights in the face of a penalty more severe than that ordered in Gollaher remains to be seen. If it is true that a harsh sentence triggers review of the fifth amendinent considerations outlined above, ${ }^{41}$ the circuits are engaged in review of the severity of sentences. ${ }^{42}$

Enforcing sentencing statutes. A final rationale often used only obtensibly to justify review of sentencing procedure concerns the enforcement of sentencing statutes. An appellate court may thus vacate even a sentence within the statutory limit on the grounds that the sentence was based upon a misconception of the sentencing statute. A straightforward application of this rationale led to sentence review in United States $v$. Lewis, ${ }^{43}$ where the sentencing judge, revoking defendant's probation but wishing to qualify defendant for early parole, mistakenly believed he had no choice but to impose the maximum sentence. The Fourth Circuit vacated the sentence. ${ }^{44}$

Less obvious applications of the appellate power to enforce sentencing statutes were explained by Judge Sobeloff ${ }^{45}$ in United States v. Wilson: ${ }^{46}$

While a sentence fixed in the exercise of discretion within statutory limits is unassailable on appeal, the appellate court may scrutinize a

40. 419 F.2d at 529-30.

41. See Scott v. United States, 419 F.2d 264 (D.C. Cir. 1969), where the appeals court followed Thomas to find procedural error after the defendant had received a sentence of fron 1 five to the maximum fifteen years.

42. See United States v. Rosenberg, 195 F.2d 583, 604 n.24 (2d Cir. 1952), citing United States v. Hoffman, 137 F.2d 416 (2d Cir. 1943) and United States v. Trypuc, 136 F.2d 900, 902 (2d Cir. 1943). The Rosenberg court recalled: "This Court has said that where it considers a sentence unduly harsh, it will be more inclined to regard as harmful an error otherwise probably harmless." 195 F.2d at 604 n.24.

43. 392 F.2d 440 (4th Cir. 1968).

44. Another case of reversal where the sentencing judge had nisinterpreted the statute is Coleman v. United States, 357 F.2d 563 (D.C. Cir. 1965). There the judge had improperly placed on the defendant the burden of showing why his death penalty should be reduced to life imprisonment.

45. Judge Sobeloff has consistently advocated appellate review of sentences: "If it is desirable to articulate generalized principles for measuring penalties, the appellate tribunal is precisely where the attempt should be made upon the foundation of the work of the district courts." Symposium-Appellate Review of Sentences, 32 F.R.D. 249, 275 (1962).

46. 450 F.2d 495 (1971). 
sentence to ascertain whether there has indeed been an exercise of discretion. 47

Thus, since a number of sentencing statutes authorize judges to consider various alternative forms of punishment, ${ }^{48}$ the failure of the sentencing judge to exercise the required discretion may result in sentence review. ${ }^{49}$

In Wilson the sentencing judge inadvertently failed to consider sentencing alternatives afforded by the Federal Youth Corrections Act; ${ }^{50}$ thus the Fourth Circuit could find statutory authority to review a sentence it avowedly considered excessive. ${ }^{51}$ Similarly, the Seventh Circuit reviewed the sentence imposed in United States $v$. Wiley $\left[1,{ }^{52}\right.$ where the sentencing judge had summarily dismissed the defendant's application for probation in conformance with his policy of not granting probation to defendants who stood trial. ${ }^{53}$ According to the Seventh Circuit, summary dismissal violated a clear statutory requirement that an application for probation "be received and acted upon by the court . ..." As in Wilson, the sentencing judge's failure to exereise discretion as required by statute was lield to have rendered the sentence reviewable.

The Wiley $I$ court, stating that the severity of Wiley's sentence was "irrelevant," nevertheless pointedly indicated the penalty's unfairness. ${ }^{55}$ In view of the weakness of the court's rationale that its review

47. Id. at 498 (emphasis added).

48. For examples of such statutes, see Weigel, Appellate Revision of Sentences: To Make the Punishment Fit the Crime, 20 Sran. L. Rev. 405, 408 (1968). Judge Weigel's data indicate that there is great disparity among district judges as to the proper "exercise of discretion" in deciding, for example, whether to use an indeterminate sentence or to impose a fixed sentence under the Juvenile Delinquency Act, 18 U.S.C. $\S \S 5031-37$ (1970).

49. See United States v. Hollis, 450 F.2d 1207 (5th Cir. 1971); United States v. Williams, 407 F.2d 940 (4th Cir. 1969). In Williams evidence before the sentencing judge indicated that Williams was an addict; the sentence was vacated because the judge failed to consider whether the defendant was entitled to treatment under the Narcotic Addict Rehabilitation Act, 28 U.S.C. $\$ \$ 3411-26,3441$ (1970). Hollis reached the same result, even though there had been no evidence before the sentencing judge to indicate addiction.

50. 18 U.S.C. $\$ 5010$ (1970).

51. The Wilson court declared: "The disparity between the crime and the pumshment is bafflimg." 450 F.2d at 498 . Wilson's crime was forging a nimety-dollar check. He was sentenced to imprisonment for three years, despite an otherwise clean record and a recommendation of probation in the presentence report.

52. 267 F.2d 453 (7th Cir. 1959). For the history of the Wiley litigation, see text accoinpanying notes 65-67 infra.

53. Id. at 455 .

54. Id. (emphasis added).

55. Id. at 456. Wiley's codefendants, more culpable and possessing worse prior 
was mandated by statute, ${ }^{56}$ it seems clear that the court was engaged in substantive review.

Exercising supervisory control. In several instances, appellate courts have abandoned the pretense of procedural review and have initiated a direct inquiry into the appropriateness of a sentence. To effectuate this substantive review, federal appeals courts have the power to supervise the lower federal courts in the establishment and maintenance of "civilized standards of procedure and evidence," " a power not limited to ensuring constitutional due process. ${ }^{58}$ For example, in Yates v. United States, ${ }^{59}$ the Supreme Court exercised its supervisory power to reduce a sentence for contempt. ${ }^{60}$ Although there is no statutory limit for a contempt penalty and the Supreme Court has therefore felt a special responsibility to ensure fairness in contempt sentences, ${ }^{61}$ no logical bar to greater exercise of supervisory power over sentencing is apparent. ${ }^{62}$

Several courts have specifically relied upon the supervisory power to attack sentences which penalized the exercise of constitutional rights. It will be recalled that in the Thomas case ${ }^{63}$ a harsh sentence had punished the defendant for his refusal to waive his fifth amendment privilege against self-incrimination. The Fifth Circuit, imposing its "notions of good policy" on the district court, found sufficient

records, received two-year sentences. Wiley was sentenced to three years, apparently only because he had stood trial.

56. The statutory language, requiring the judge to "act upon" the application for probation, could be construed to require only disposition. See id. at 458 (Hastings, J., dissenting in part): "The motion [for probation] was received and acted upon unfavorably."

57. McNabb v. United States, 318 U.S. 332, 340 (1943). See Thomas v. United States, 368 F.2d 941, 947 (5th Cir. 1966), where the court cites authority that it "is now well settled that the Courts of Appeals, as well as the Supreme Court, have . . . supervisory control ...."

58. See Fay v. New York, 332 U.S. 261, 287 (1947):

Over federal proceedings we may exert a supervisory power with greater freedom to reflect our notions of good policy than we may constitutionally exert over proceedings in state courts, and these expressions of policy are not necessarily embodied in the concept of due process.

59. 356 U.S. 363 (1958).

60. After reversing ten of defendant's eleven convictions for contempt, the Supreme Court remanded with "gentle intimations" that a reduced sentence was in order. When the same sentence was reimposed, the Supreme Court stated that "the District Court appears not to have exercised its discretion" and ordered a reduced sentence. Id. at $366-67$.

61. See Green v. United States, 356 U.S. 165, 188 (1958); Yates v. United States, 356 U.S. 363, 366-67 (1957).

62. For a discussion of whether the supervisory power is "ancillary to the appellate power," see 74 YALE L.J. 379, 384-85 n.35 (1964).

63. For a discussion of Thomas, see text accompanying notes 34-36 supra. 
authority in its supervisory power to vacate the sentence, even though the appeals court was unable to find a technical violation of the defendant's fifth amendment rights. ${ }^{64}$

In the Wiley $I$ case discussed above, ${ }^{65}$ it was clear that the judge had stiffened the sentence because the defendant stood trial rather than plead guilty. On remand for resentencing, under instructions from the Seventh Circuit to sentence without regard to that factor, the district judge reimposed the same sentence without rearticulating his reasons. On the second appeal, ${ }^{66}$ the Seventh Circuit thus was faced with a difficult situation: the sentence was too severe; but since the trial judge had stated no reasons for its reimposition, the sentence was immune from "procedural" scrutiny under Townsend. Like the Third Circuit in a later case, ${ }^{67}$ the Seventh Circuit could have dealt with the absence of a reviewable record by simply presuming that the sentencing judge had considered tainted factors. But the Wiley II court, unwilling so to speculate, exercised its supervisory power and straightforwardly engaged in substantive review of the sentence itself, setting it aside and remanding with directions for a reduced sentence.

Reviewing abuse of discretion. The most direct assault on the rule against sentence review has been mounted by several courts propounding the novel view that even a sentence within statutory limits may constitute an abuse of discretion.

The traditional view of the sentencing judge's unbridled discretion is exemplified by the case of Peterson v. United States. ${ }^{68}$ Upon sentencing Peterson to three years' imprisonment for the crime of stealing a postage stamp, the trial judge stated his belief that the defendant was also guilty of subornation of perjury, an offense for which he had not been indicted. Noting that the sentence seemed "oversevere," the Fourth Circuit nevertheless adopted the Freeman ${ }^{69}$ court's description of the breadth of a sentencing judge's discretion:

The question of the nature of the sentence was one which rested in

64. For a discussion of the fifth amendment implications of Thomas, see notes 35-36 supra and accompanying text.

65. For a discussion of Wiley I, see text accompanying notes 52-56 supra.

66. United States v. Wiley [II], 278 F.2d 500 (7th Cir. 1960).

67. Virgin Islands v. Turner, 409 F.2d 102 (3d Cir. 1969). See text accompanying notes 31-33 supra.

68. 246 F. 118 (4th Cir. 1917). For a long-range history of the growth of sentencing-judge discretion, see Pugh \& Carver, Due Process and Sentencing: From Mapp to Mempa to McGautha, 49 TEx. L. Rev. 25, 26-27 (1970).

69. Freeman v. United States, 243 F. 353,357 (9th Cir. 1971). See text accompanying notes 7-11 supra. 
the discretion of the court below, a discretion which will not be reviewed in this court in any case where the punishment assessed is within the statutory limits. ${ }^{70}$

The continuing strength of this principle is illustrated by the fact that the Wiley II court was unable to find that the trial judge had "abused his discretion" in reimposing a heavy sentence, even when contrary to clear appellate suggestion that the sentence was unfair. ${ }^{71}$

Leach $v$. United States ${ }^{72}$ presented similar circumstances but a different conclusion. There, the lower court disregarded the appellate court's suggestion ${ }^{73}$ that it order a presentence mental examination of the defendant. Though the sentence imposed did not exceed the statutory limit, the District of Columbia Circuit held that the sentencing judge's refusal to follow the appellate "suggestion" constituted an abuse of discretion. ${ }^{74}$

Two recent cases in the Sixth and Eighth Circuits-United States v. McKinney ${ }^{75}$ and Woosley $v$. United States ${ }^{76}$-represent the greatest incursions yet into the area of the sentencing judge's discretion. Both courts confronted essentially the same fact situations. The defendants, of good record and reputation, refused to obey induction orders and were convicted of violating the Selective Service laws. The trial judges, following the well established policies of their respective districts, automatically imposed the maximum five-year sentence. Exercising what they thought to be complete discretion, the trial judges in effect held that the harmful consequences of Selective Service violations predominated over the relrabilitation of draft resisters. ${ }^{\mathbf{7 7}}$

In McKinney, the Sixth Circuit held that the habitual imposition of a maximum sentence constituted "a gross abuse of discretion."78

70. 246 F. at 119. Accord, e.g., United States v. Fallon, 407 F.2d 621 (7th Cir.), cert. denied, 395 U.S. 908 (1969); United States v. Restaino, 405 F.2d 628 (3d Cir. 1968), cert. denied, 394 U.S. 904 (1969); United States v. Sacher, 182 F.2d 416 (2d Cir. 1950). But see United States v. Moore, 484 F.2d 1284, 1288-89 (4th Cir. 1973) (concurring opinion).

71. 278 F.2d at 502 .

72. 334 F.2d 945 (D.C. Cir. 1964), noted in 74 Yale L.J. 379 (1964).

73. Leach v. United States, 320 F.2d 670, 673 (D.C. Cir. 1963).

74. 334 F.2d at 948 .

75. 466 F.2d 1403 (6th Cir. 1972), noted in 7 SuffolK U.L. Rev. 1128 (1973).

76. 478 F.2d 139 (8th Cir. 1973).

77. See Woosley v. United States, 478 F.2d 139, 143 (8th Cir. 1973); United States v. McKinney, 466 F.2d 1403, 1404-05 (6th Cir. 1972). One judge's reason for always imposing the maximum sentence is quoted in United States v. Charles, 460 F.2d 1093, 1095 (6th Cir. 1972): "[W]hen you consider a man has just willfully ... refused to serve his country, it would seem to be a travesty that he would serve less time at confineinent . . . than a man who went on and served."

78. 466 F.2d at 1405 . 
The court ruled that the sentencing judge's rigid procedure was contrary to a policy, approved by the Supreme Court in Williams $v$. New York $_{,}{ }^{79}$ that a sentence should reflect the circumstances of individual defendants as well as the best interest of the rest of society. ${ }^{80}$ The appellate court thereupon reduced McKinney's sentence to one year.

The Woosley court agreed that this inflexible sentencing procedure was contrary to the Supreme Court's mandate. ${ }^{81}$ But the Eighth Circuit, sitting en banc, further found an abuse of discretion in the severity of the sentence itself. ${ }^{82}$ While basing its holding primarily upon the character and circumstances of the offender, ${ }^{83}$ the court also noted the disparity between Woosley's five-year sentence and the lighter sentences usually imposed in other jurisdictions on violators of the draft laws. ${ }^{84}$ In addition, the court focused on the sentencing judge's failure to explain his reasons for the severe sentence. ${ }^{85}$ The Eighth Circuit's willingness to probe into all aspects of Woosley's sentence-procedural and substantive-well illustrates the decline of the rule against sentence review.

\section{Prospects for the Rule}

The inost likely source of sweeping change of the rule against review is legislation. ${ }^{86}$ In 1967 the Senate passed a bill providing that

79. 337 U.S. 241 (1949). Holding that sentencing judges are free from evidentiary restrictions on the material they may consider, the Court approved, but did not mandate, "individualizing punishment." Id. at 247-49. See also Williams v. Oklahoma, 358 U.S. $576,585-86$ (1959).

80. 466 F.2d at $1404-05$.

81. Woosley v. United States, 478 F.2d 139, 143 (8th Cir. 1973): "We believe that we have the power to examine and review a sentence if it is shown to have been imposed on a mechanical basis."

Uniform sentencing of draft resisters has also troubled the Second Circuit. In a recent case, that court unanimously expressed its opposition to any fixed sentencing policy for Selective Service violators. However, the majority ruled that the trial judge in the case under consideration had not abused his discretion. See United States v. Baker, No. 73-1598 (2d Cir. Nov. 7, 1973), reported in 170 N.Y.L.J., Nov. 8, 1973, at 1 , col. 3 .

82. 478 F.2d at 146-48. Compare United States v. Fallon, 407 F.2d 621, 624 (7th Cir.), cert. denied, 395 U.S. 908 (1969), where the appeals court was unable to find an abuse of discretion though it explicitly disapproved the maximum five-year sentence imposed for a Selective Service violation.

83. $478 \mathrm{~F} .2 \mathrm{~d}$ at $147-48$.

84. Id. at 147. The court took judicial notice of data indicating, for instance, that in 1971 most convicted draft resisters received probation and only 2.8 percent received the maximum sentence. Id.

85. Id.

86. See Gore v. United States, 357 U.S. 386, 393 (1958), where Justice Frankfurter noted that "the inuch mooted problems relating to the power of the judiciary to review sentences" are "peculiarly questions of legislative policy." 
"the court of appeals may affirm, reduce, modify, vacate, or set aside the sentence imposed ...."87 The House failed to act on the bill, and the proposal has not since become law. ${ }^{88}$ However, in 1970 both houses of Congress approved appellate review where a defendant was sentenced as a "dangerous special offender" under the Organized Crime Control Act:"89 "The court of appeals . . may . . . impose or direct the imposition of any sentence which the sentencing court could originally have imposed . . . ."

Since the rule against sentence review was developed by appellate court judges, theoretically any circuit could rescind the rule by a reinterpretation of the statutory grant of appellate power to "modify, vacate, set aside or reverse any judginent, decree or order . . . ."91 Indeed, it appears that the Sixth and Eighth Circuits have rescinded the rule in their novel holdings that a trial judge can abuse his discretion in imposing a sentence within statutory limits. It may be that other circuits will follow suit when confronted with excessive sentences that are unassailable on procedural grounds. ${ }^{92}$ The Supreme Court, of course, could lay down the much-needed uniform rule of sentence review, but in recent years it has avoided the problem. ${ }^{93}$

The enumerated exceptions have, however, greatly weakened the general rule that a sentencing judge's decision as to the proper severity of punishment for a crime is unreviewable. Due to the breadth of these exceptions and the increased appellate willingness to reduce oversevere sentences, a trial judge can completely avoid sentence review only by keeping secret the grounds of his decision.

\section{A Reviewable Record}

In order to ensure a more uniform application of the exceptions to the rule of nonreview, an appellate court should have two kinds of information about the district judge's sentencing decision. First, the reviewing court should know what material the sentencing judge con-

87. S.1540, 90th Cong., 1st Sess. \$ 3742(c) (1967).

88. An identical bill is again pending before the Senate as this Note goes to press. S.716, 93d Cong., 1st Sess. (1973).

89. 18 U.S.C. $\$ \S 3575$ et seq. (1970). For the detailed statutory definition of "dangerous special offender," see $i d$. $\$ 3575(\mathrm{e})(1)-(3)$.

90. $I d$. $\$ 3576$.

91. 28 U.S.C. \& 2106 (1970).

92. See 170 N.Y.L.J., Nov. 8, 1973, at 1, col. 3 (discussion of United States v. Baker, No. 73-1598 (2d Cir. 1973)).

93. See, e.g., Weston v. United States, 404 U.S. 1061 (1972), denying cert. to 448 F.2d 626 (9th Cir. 1971); Gollaher v. United States, 396 U.S. 960, denying cert. to 419 F.2d 520 (9th Cir. 1969). 
sidered with regard to the defendant's prior criminal record and to his prospects for rehabilitation. That information is normally found in a presentence report. Second, the appeals court should be made aware of the trial judge's reasons for imposing a particular sentence. At present, inquiry into the decision-making process for sentencing has been all but foreclosed, since disclosure of the presentence report and of the reasons for the sentence is subject to the discretion of the trial judge. For effective review, a sentencing judge must be required to "leave a trail" by which his decision can be reviewed.

\section{Disclosure of the Presentence Report}

Under rule 32(c)(2) of the Federal Rules of Criminal Procedure, the presentence report, compiled "unless the court otherwise directs," "94 is disclosed to the defendant and thus becomes a part of the record at the discretion of the trial judge: ${ }^{95}$

The report . . . shall contain any prior criminal record of the defendant and such information about his characteristics, his financial condition and the circumstances affecting his behavior as may be helpful in imposing sentence. ... The court before imposing sentence may disclose to the defendant or his counsel all or part of the material contained in the report .... and afford an opportunity to the defendant or his counsel to comment thereon. ${ }^{96}$

Within most circuits, this discretion is not routinely exercised. ${ }^{97}$ One survey published in the mid-1960's asked district judges whether it was their "practice" to "divulge any information contained in presentence reports to defense counsel." Almost sixty percent of the responding judges indicated that indeed it was not their practice to divulge such information. ${ }^{98}$ Moreover, these discretionary decisions to withhold

94. FED. R. CRIM. P. 32(c)(1).

95. See 28 U.S.C. \& 753(b) (1970).

96. FED. R. CRIM. P. 32(c)(2) (emphasis added).

97. But see United States v. Powell, No. 73-1210 (4th Cir. Nov. 14, 1973) (report should be withheld only where there are "sound reasons for preserving secrecy"); United States v. Picard, 464 F.2d 215 (1st Cir. 1972) (requiring disclosure of all material in the report which was actually relied upon, with a disclaimer of reliance upon undisclosed information); United States v. Janiec, 464 F.2d 126 (3d Cir. 1972) (requiring disclosure of all rule 32 (c)(2) material in order to guard agamst clerical error); Buchea v. Sullivan, 262 Ore. 222, 497 P.2d 1169 (1972) (requiring complete disclosure).

98. Higgins, Confidentiality of Presentence Reports, 28 Albany L. Rev. 12, 15 (1964). One hundred forty-six federal district judges responded to this particular question.

In one exceptional case, a court of appeals has decreed minimal standards for disclosure: "The sentencing court slould apprise [the defendant] ... of at least such 
the presentence report have been consistently upheld on appeal. ${ }^{\text {10 }}$

The three arguments generally advanced to support nondisclosure $^{100}$ are (1) that disclosure would result in reports of poor quality as previously confidential sources dried up, (2) that disclosure would delay the sentencing process, and (3) that the probation officers who compile reports should be trusted to use only accurate information. These arguments have been copiously rebutted. ${ }^{101}$ The experience of three jurisdictions with a practice of disclosure has imdicated that sources do not dry up. ${ }^{102}$ As for delay, of 167 federal district judges responding to the above poll,

not one judge with a practice of disclosure complained that the sentencing process had become unduly protracted. . . . Several judges noted ... that disclosure permits . . the discussion to be directed to pertinent considerations. ${ }^{103}$

Finally, though probation officers are generally trustworthy, mistakes in the presentence report are common ${ }^{104}$ because probation officers often shoulder extremely heavy work loads. ${ }^{105}$ In short, the

pivotal matters of public record as the convictions and charges of crime, with date and place, attributed to him in the report." Baker v. United States, 388 F.2d 931, 933 (4th Cir. 1968). Presumably it is not the practice of most of the judges responding to the Higgins poll even to disclose such matters.

99. See 2 C. Wright, Federal Practice and Procedure $\$ 524$ n.60 (1969) (citing cases). But see United States v. Bryant, 442 F.2d 775 (D.C. Cir.), cert. denied, 402 U.S. 932 (1971) (district judge's refnsal to disclose held an abuse of discretion on the particular facts of the case).

100. See, e.g., Parsons, The Presentence Investigation Report Must Be Preserved as a Confidential Document, 28 Fed. Probation 3, 4-5, 7 (1964); Roche, The Position for Confidentiality of the Presentence Investigation Report, 29 ALBANY L. REv. 206 (1965).

101. See, e.g., Lehrich, The Use and Disclosure of Presentence Reports, 47 F.R.D. 225, 238-40 (1969). See also Wyzanski, A Trial Judge's Freedom and Responsibility, 65 HARV. L. REv. 1281, 1291-92 (1952).

102. See Bach, The Defendant's Right of Access to Presentence Reports, 4 Crim. L. Bull. 160, 164 (1968) (California); Lorensen, The Disclosure to Defense of Presentence Reports in West Virginia, 69 W. VA. L. REv. 159, 163-64 (1967) (West Virginia); Symposium, Discovery in Federal Criminal Cases, 33 F.R.D. 47, 126-27 (1963) (Maryland federal district courts).

103. Higgins, supra note 98 , at 32 .

104. One presentence investigator mistakenly reported that the defendant had spent most of his life in jail and had escaped from a California jail. No doubt as a result, the defendant was sentenced to twenty-one years for check forgery. See Lehrich, supra note 101, at 241-44 (citing further examples). For a description of typical weaknesses (besides falsehood) of presentence reports, see Bennings v. United States, 343 F.2d 283, 285 n.9 (D.C. Cir. 1964) (Bazelon, C.J., dissenting).

105. "[D]uring 1963522 federal probation officers completed 26,226 presentence investigations, 6,860 prerelease investigations for the Board of Parole, and supervised nearly 39,000 defendants on probation." Lehrich, supra note 101, at 241. 
reasons for relying upon the district judge's discretion as to disclosure of the presentence report do not appear persuasive:

It seems an unusual kind of discretion to give, for it is difficult for the court to exercise it in an intelligent fashion. The reason for disclosure is the fear that the report inay be incomplete or inaccurate, and yet these flaws will hardly appear on the face of the document. ${ }^{106}$

In addition to policy considerations, it lias been argued that due process requires disclosure of the presentence report. ${ }^{107}$ Similarly, since defendants are accorded a right of confrontation at trial, it seems no less desirable that there be soine sucli right at the equally crucial sentencing stage. ${ }^{108}$ Review of a severe sentence is too important to depend partly, as it does now, on fortuitous disclosure of the presentence report.

The arguments for nondisclosure of the presentence report are not only unconvincing, but they have been inade without reference to the increased availability of sentence review. In Townsend v. Burke, review was justified because the defendant was sentenced on the basis of assumptions concerning his criminal record which were found to be materially untrue. ${ }^{109}$ In United States $v$. Weston, unreliable information in the presentence report prompted review. ${ }^{110}$ If appeals courts, independent of the district judge, are willing to assess the proper weiglit to be given items in the report, then minimal fairness to the defendant mandates disclosure of the report. As stated by Judge Browning in his separate opinion in Verdugo v. United States: ${ }^{111}$ "It would seem anoinalous to liold that although a sentence based upon erroneous information which counsel could correct violates due process, counsel need not be given access to that information."112

Changes in the rule of discretionary disclosure are unlikely to come froin the Supreme Court, which has denied certiorari in cases go-

106. 2 C. WRIGHr, supra note $99, \S 524$.

107. See Pugh \& Carver, supra note 68, at 37-39.

108. Approximately seventy percent of federal defendants plead guilty. See Judiciat CONFERENCE OF THE UNITEd STATES, RePORT OF THE DIRECTOR OF THE ADMINISTRAtive OfFice of the United STATES Courts 261 (1968). For those defendants, the few procedural protections afforded at sentencing are particularly significant, inasmuch as the guilty plea negates the protection offered by safeguards that apply only during trial.

109. 334 U.S. 736, 741 (1948).

110. 448 F.2d 626 (9th Cir. 1971). See text accompanying notes 25-29. In Weston the sentencing judge did disclose certain portions of the presentence report at trial.

111. 402 F.2d 599 (9th Cir. 1968) (Browning, J., separate opinion), cert. denied, 402 U.S. 961 (1971).

112. Id. at 613 . 
ing both ways on the question of whether a district judge abused his discretion in refusing to disclose the presentence report. ${ }^{113}$ However, in 1970 the Advisory Committee on Criminal Rules recommended that disclosure be mandatory in the absence of an explained finding by the district judge that harm "to the defendant or to other persons" would result from disclosure. In the event of such a finding, under the proposed revision of rule 32 , the district judge must disclose a "summary of the factual information contained [in the report] to be relied on in determining sentence."114 Acceptance of the Advisory Committee's proposal would be a major step toward effective review; and it would go far to ensure that sentences are not based upon false, unreliable, or inaterially incomplete information.

\section{Statement of Reasons for a Sentence}

Like the presentence report, the reasons for the imposition of a particular sentence are generally mired in the vagaries of judicial discretion. At present, district judges inust justify the sentences they impose in only two general situations. ${ }^{115}$ In North Carolina $v$. Pearce, ${ }^{116}$ the Supreme Court held that where a defendant's sentence is increased after a new trial, the judge's reasons for the increase "must be made part of the record, so that the constitutional legitimacy of the increased sentence may be fully reviewed on appeal."117 Secondly, under Title X of the Organized Crime Control Act of 1970, the "reasons for the sentence imposed" must be stated wliere a district court sentences a defendant as a "dangerous special offender." 118

113. See Bryant v. United States, 402 U.S. 932, denying cert. to 442 F.2d 775 (D.C. Cir. 1971); Bakewell v. United States, 400 U.S. 964, denying cert. to 430 F.2d 721 (5th Cir. 1970).

114. Proposed Fed. R. CRm. P. 32.2(c)(2), reprinted in 48 F.R.D. 553, 615 (1970).

115. Circuit courts of appeals have occasionally demanded statements of reasons for sentences in certain other isolated contexts. See, e.g., McGee v. United States, 462 F.2d 243 (2d Cir. 1972); Umited States v. Latimer, 415 F.2d 1288 (6th Cir. 1969).

116. 395 U.S. 711 (1969).

117. Id. at 726. The trial judge's reasons for an increased sentence "must be based upon objective information concerning identifiable conduct on the part of the defendant occurring after the time of the original sentencing proceeding," $i d$., so as to avoid penalizing defendant's exercise of his right to appeal.

Similarly, in the Ninth Circuit, whenever plea-bargaining has broken down and the judge imposes a heavier sentence than one previously discussed, "the record must affirmatively show that the court sentenced the defendant solely upon the facts of his case and his personal history, and not as punishment for his refusal to plead guilty." United States v. Stockwell, 472 F.2d 1186, 1188 (9th Cir.), cert. denied, 411 U.S. 948 (1973).

118. 18 U.S.C. $\$ 3575$ (1970). The district court must also identify " the information relied upon." See note 89 supra and accompanying text. 
Two major arguments have been advanced in support of the general rule that district judges need not justify their sentences. One is that sentencing is not amenable to structured decision-making: "Frequently, the decision will rest on the application of unarticulated principles and factors lying at the threshold of the conscious." ${ }^{119}$ Presumably, those "unarticulated principles" have to do with the ultimate goals of rehabilitation, deterrence, and punishment. Although it has been argued that trial and appellate courts should more closely analyze sentences as possible means of attaining those goals, ${ }^{120}$ it should be noted that certain less cosmic "reasons" for severe sentences have been designated as improper. For example, the fact that the defendant stood trial ${ }^{121}$ or refused to admit his guilt ${ }^{122}$ should in most jurisdictions be irrelevant to the sentencing decision. Such reasons now become part of the record only if the sentencing judge is unusually frank or if he blunders. To say that recorded reasons will not necessarily be honest ${ }^{123}$ overlooks the potentially benign, standardizing effect of appellate instruction as to proper reasoning in sentencing. ${ }^{124}$

The other principal argument for the present system is that the recording of sentence justification would place a useless burden on the district judge's time. But the importance of reasoned sentencing clearly warrants the burden. According to District Judge Frankel:

The duty to give an account of the decision is to promote thought by the decider, to compel him to cover the relevant points, to help him to eschew irrelevancies-and, finally, to make him show that these necessities have been served. . . .

Knowing this to be so, we apply it to affairs of clearly less consequence, yet we place no burden of explanation upon the judge who decides that the defendant before him must be locked up for ten years rather than five or one. ${ }^{125}$

119. United States v. Schipani, 315 F. Supp. 253,259 (E.D.N.Y.), aff'd, 435 F.2d 26 (2d Cir. 1970), cert. denied, 401 U.S. 983 (1971). Compare Wyzanski, supra note 101, at 1292-93:

Our judgment, they say, is better than our reasons. . . . [B]ut there is grave danger that a sentencing judge will allow his emotion or other transient factors to sway him. .... Moreover, the explicit utterance of relevant criteria serves as a guide for future dispositions both by him and other judges.

120. See M. FRANKEL, supra note 3 , at viii.

121. See United States v. Wiley, 267 F.2d 453 (7th Cir. 1959).

122. See Thomas v. United States, 368 F.2d 941 (5th Cir. 1966).

123. See Weigel, supra note 48, at 421: "Plausible rationalizations can often be adduced to support excessive sentences . . . ."

124. See K. Davis, Discretionary Justice: A Preliminary Inquiry 133 (1969): "All the elements of structuring are needed [in sentencing]-open plans, policy statements and rules, findings and reasons, and open precedents."

125. M. FRANBeI, supra note 3, at 41 . 
It may be that legislation will soon mandate a reviewable record. Passed by the Senate in 1967 and again pending, the same bill which provides for appellate review of sentences also stipulates: "In each felony case in which sentence of imprisonment or death is imposed the judge shall state for the record his reasons for selecting that particular sentence."126 The bill recognizes, as should the courts, that without a reviewable record, expanded review of sentences cannot change the current situation in which excessive and disparate sentences are common. ${ }^{127}$

\section{CONCLUSTON}

Many of the cases discussed in this Note stand for the proposition that sentencing-judge discretion, while useful for tailoring sentences to individual defendants, should not be unlimited. Appeals courts are now reviewing matters that were previously thought to be within the sentencing judge's sole discretion. However, for practical purposes, sentence review depends on a record which indicates the grounds of the sentence. If defendants are held entitled to review of improper sentences, as they increasmgly are, that entitlement is too important to be frustrated by a trial judge's unwarranted belief that the sentencing process is best kept secret.

126. S.716, 93d Cong., 1st Sess., $\$ 3742(\mathrm{e})(1973)$; S.1540, 90th Cong., 1st Sess., $\S 3742(\mathrm{e})(1967)$.

127. For a brief indication of the excessiveness and disparity of some sentences, see notes 2-3 supra and accompanying text. 